\title{
p38 MAP kinase modulates liver cell volume through inhibition of membrane $\mathrm{Na}^{+}$permeability
}

\author{
Andrew P. Feranchak, ${ }^{1}$ Tomas Berl, ${ }^{2}$ Juan Capasso, ${ }^{2}$ Paul A. Wojtaszek, ${ }^{2}$ Jiahuai Han, ${ }^{3}$ \\ and J. Gregory Fitz ${ }^{2}$ \\ ${ }^{1}$ Department of Pediatrics, and \\ ${ }^{2}$ Department of Medicine, University of Colorado Health Sciences Center, Denver, Colorado, USA \\ ${ }^{3}$ Department of Immunology, Scripps Research Institute, La Jolla, California, USA
}

Address correspondence to: Andrew Feranchak, Campus Box B-158, Room 6412, University of Colorado

Health Sciences Center, 4200 East 9th Avenue, Denver, Colorado 80262, USA.

Phone: (303) 315-3515; Fax: (303) 315-3507; E-mail: drew.feranchak@UCHSC.edu.

Received for publication January 1, 2001, and accepted in revised form September 24, 2001.

In hepatocytes, $\mathrm{Na}^{+}$influx through nonselective cation (NSC) channels represents a key point for regulation of cell volume. Under basal conditions, channels are closed, but both physiologic and pathologic stimuli lead to a large increase in $\mathrm{Na}^{+}$and water influx. Since osmotic stimuli also activate mitogen-activated protein (MAP) kinase pathways, we have examined regulation of $\mathrm{Na}^{+}$permeability and cell volume by MAP kinases in an HTC liver cell model. Under isotonic conditions, there was constitutive activity of p38 MAP kinase that was selectively inhibited by SB203580. Decreases in cell volume caused by hypertonic exposure had no effect on $\mathrm{p} 38$, but increases in cell volume caused by hypotonic exposure increased p38 activity tenfold. $\mathrm{Na}^{+}$currents were small when cells were in isotonic media but could be increased by inhibiting constitutive p 38 MAP kinase, thereby increasing cell volume. To evaluate the potential inhibitory role of p38 more directly, cells were dialyzed with recombinant $\mathrm{p} 38 \alpha$ and its upstream activator, MEK-6, which substantially inhibited volume-sensitive currents. These findings indicate that constitutive $\mathrm{p} 38$ activity contributes to the low $\mathrm{Na}^{+}$permeability necessary for maintenance of cell volume, and that recombinant p38 negatively modulates the set point for volume-sensitive channel opening. Thus, functional interactions between p38 MAP kinase and ion channels may represent an important target for modifying volume-sensitive liver functions.

J. Clin. Invest. 108:1495-1504 (2001). DOI:10.1172/JCI200112190.

\section{Introduction}

Mitogen-activated protein (MAP) kinases are ubiquitous serine/threonine protein kinases that play an important role in translating extracellular signals to the nucleus $(1,2)$. Among these, p38 MAP kinase represents a human homologue of the Saccharomyces cerevisiae HOG-1 gene product, a yeast MAP kinase required for cellular osmoregulation $(2,3)$. p38 MAP kinase is specifically regulated by changes in environmental osmolarity by dual tyrosine/threonine phosphorylation (4) mediated by two MAP kinase kinases (MEKs), MEK-3 and MEK-6 $(5,6)$. Members of the p38 signaling complex are also activated in response to lipopolysaccharides, proinflammatory cytokines, and ultraviolet radiation $(4,7,8)$. It has been shown that p38 plays an important role in the cellular response to osmotic changes: inhibition of p38 by SB203580 prevents volume-sensitive induction of multiple mRNAs $(2,9,10)$.

In addition to the effects on p38, change in cell volume also appears to be an important stimulus for modulation of other members of the MAP kinase family, including JNK and ERK $(2,9)$. Cell volume homeostasis is mandatory for maintenance of cellular integrity, but also represents a means of coupling changes in membrane transport to other organ-specific functions. An increase in cell volume, for example, appears to serve as a signal regulating many liver functions, stimulating protein synthesis, secretion, and gene expression. In addition to these physiologic roles, failure to regulate cell volume has been implicated in liver cell injury associated with alcohol, ischemia/reperfusion, and organ preservation (11-13). Thus, one function of MAP kinases may be to mediate volume-sensitive changes in gene expression.

Recent studies suggest that p38 MAP kinase is constitutively active in certain cells, and may also be capable of regulating membrane transport through direct effects on ion channels $(14,15)$. In hepatocytes, membrane $\mathrm{Na}^{+}$ permeability is low under basal conditions, but decreases in cell volume stimulate an adaptive response that involves $\mathrm{Na}^{+}$influx through opening of nonselective cation (NSC) channels. The resulting water influx leads to restoration of cell volume toward basal values, a process referred to as regulatory volume increase (RVI) $(16,17)$. Since MAP kinases exhibit volume-sensitive changes in activity, the purpose of these studies was to assess the potential role of $\mathrm{p} 38$ and other MAP kinase signaling pathways in volume-dependent changes in membrane $\mathrm{Na}^{+}$permeability. The findings suggest that 
constitutive activity of p38 MAP kinase plays an essential role in maintenance of cell volume through tonic inhibition of $\mathrm{Na}^{+}$-permeable ion channels.

\section{Methods}

Cell culture. All studies were performed in HTC cells, a model rat hepatoma cell line that expresses ion channels and signaling pathways similar to those found in primary rat hepatocytes $(18,19)$. Decreases in HTC cell volume, stimulated by exposure to hypertonic buffer or oxidative stress, are followed by opening of $\mathrm{Na}^{+}$-permeable channels in the plasma membrane (20). Cells were passaged at weekly intervals and maintained in MEM containing $\mathrm{HCO}_{3}{ }^{-}$(Invitrogen, Grand Island, New York, USA) supplemented with $10 \%$ heat-inactivated FBS, Lglutamine $(2 \mathrm{mM})$, penicillin $(100 \mathrm{IU} / \mathrm{ml})$, and streptomycin $(100 \mu \mathrm{g} / \mathrm{ml})$ as previously described (21).

Measurement of $\mathrm{Na}^{+}$currents. Membrane $\mathrm{Na}^{+}$currents were measured using whole-cell patch-clamp techniques. Cells on a cover slip were mounted in a chamber (volume $\sim 400 \mu \mathrm{l}$ ) and perfused at $4-5 \mathrm{ml} / \mathrm{min}$ with a standard extracellular solution containing (in $\mathrm{mM}$ ): $140 \mathrm{NaCl}, 4 \mathrm{KCl}, 1 \mathrm{CaCl}_{2}, 2 \mathrm{MgCl}_{2}, 1 \mathrm{KH}_{2} \mathrm{PO}_{4}, 10$ glucose, and 10 HEPES/NaOH ( $\mathrm{pH}$ 7.40). The standard intracellular (pipette) solution for whole-cell recordings contained (in mM): $130 \mathrm{KCl}, 10 \mathrm{NaCl}, 2 \mathrm{MgCl}_{2}, 10$

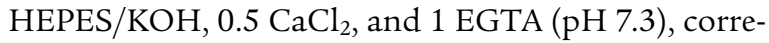
sponding to a free $\left[\mathrm{Ca}^{2+}\right]$ of approximately $100 \mathrm{nM}(22)$. Patch pipettes were pulled from 7052 glass (Garner Glass Co., Claremont, California, USA) and had a resistance of 3-10 M $\Omega$. Recordings were made with an Axopatch ID amplifier (Axon Instruments Inc., Foster City, California, USA), and were digitized $(1 \mathrm{kHz})$ for storage on a computer and analyzed using PCLAMP version 6.0 (Axon Instruments Inc.) as previously described $(23,24)$. Three voltage protocols were used: (a) holding potential $-40 \mathrm{mV}$, with $200-\mathrm{ms}$ steps to 0 $\mathrm{mV}$ and $-80 \mathrm{mV}$ at 10 -second intervals (for real-time tracings); (b) holding potential $-40 \mathrm{mV}$, with 400-ms steps from $-100 \mathrm{mV}$ to $+100 \mathrm{mV}$ in $20-\mathrm{mV}$ increments; and (c) holding potential $-40 \mathrm{mV}$ and voltage ramp from $-100 \mathrm{mV}$ to $+100 \mathrm{mV}$ over $200 \mathrm{~ms}$. Current-voltage $(\mathrm{I}-\mathrm{V})$ relationships were generated from the "step" or "ramp" protocols as indicated. Pipette voltages are referred to the bath. In the whole-cell configuration, pipette voltage corresponds to the membrane potential, and upward deflections of the current trace indicate outward membrane current. Results are compared with control studies measured on the same day to minimize any effects of day-to-day variability, and are reported as current density $(\mathrm{pA} / \mathrm{pF})$ to normalize differences in cell size (21).

Cell size measurements. Mean cell volume was measured in cell suspensions by electronic cell sizing with a Coulter Multisizer and AccuComp software version 1.19 (Coulter International Inc., Hialeah, Florida, USA) using an aperture of $100 \mu \mathrm{m}$, as previously described (25). Cells in subconfluent culture were harvested with $0.05 \%$ trypsin, suspended in cell culture media, cen- trifuged for 1 minute at approximately $1,000 \mathrm{~g}$, resuspended in $3 \mathrm{ml}$ of isotonic buffer, and incubated with gentle agitation for 30-45 minutes. Aliquots $(-500 \mu \mathrm{l})$ of cell suspension were added to $20 \mathrm{ml}$ of isotonic or hypertonic (40\% increase in $\mathrm{NaCl}$ or $100 \mathrm{mM}$ sucrose, $\sim 395 \mathrm{mOsm}$ ) buffer. Measurements of approximately 20,000 cells were compared with basal values (time 0 ) at specified timepoints after exposure to isotonic or hypertonic buffer. Changes in value are expressed as relative volume normalized to the basal value. Experimental reagents were added as indicated.

MAP kinase activity. Measurements of MAP kinase activity were performed as previously reported, with minor modifications $(26,27)$. Cells were exposed to hypotonic (100 mOsm) or hypertonic ( $-500 \mathrm{mOsm})$ treatment for 5 minutes, then immediately homogenized in ice-cold lysis buffer (50 mM $\beta$-glycerophosphate ( $\mathrm{pH} 7.2$ ), 0.5\% Triton X-100, $0.1 \mathrm{mM}$ sodium vanadate, $2 \mathrm{mM} \mathrm{MgCl}_{2}, 1$ mM EGTA, $1 \mathrm{mM}$ DTT, $2 \mu \mathrm{g} / \mathrm{ml}$ leupeptin, and $4 \mu \mathrm{g} / \mathrm{ml}$ aprotinin). The lysate was centrifuged at $4^{\circ} \mathrm{C}$ for $10 \mathrm{~min}$ utes at $10,000 \mathrm{~g}$, and supernatants were adjusted to $100-200 \mu \mathrm{g}$ protein in $0.5 \mathrm{ml}$.

For measurement of JNK activity, $100 \mu \mathrm{l}$ of $10 \%$ GST-c-Jun agarose beads was added. After 2 hours of rocking incubation at $4^{\circ} \mathrm{C}$, the adsorbed proteins were washed three times in lysis buffer and resuspended in $40 \mu \mathrm{l} \beta$-glycerophosphate (50 mM, pH 7.2), $0.1 \mathrm{mM}$ sodium vanadate, $10 \mathrm{mM} \mathrm{MgCl}_{2}$, and $100 \mu \mathrm{M}$ $\gamma\left[{ }^{32} \mathrm{P}\right] \operatorname{ATP}(5,000 \mathrm{cpm} / \mathrm{pmol})$. The reactions were incubated for 20 minutes at $30^{\circ} \mathrm{C}$, then stopped by the addition of hot SDS sample buffer. The lysates were heated in a boiling water bath for 5 minutes and subsequently subjected to SDS-PAGE on a $10 \%$ polyacrylamide gel, followed by autoradiography. The bands corresponding to phosphorylated c-Jun were excised and counted in a liquid scintillation counter.

For measurement of ERK activity, $2.5 \mu \mathrm{l}$ each of antisera against ERK1 and ERK2 (Sc-94 and Sc-93 rabbit polyclonal antisera; Santa Cruz Biotechnology Inc., Santa Cruz, California, USA) was added, along with $100 \mu \mathrm{l}$ 10\% protein A-Sepharose (Pharmacia Biotech Inc., Piscataway, New Jersey, USA). After 2 hours of rocking incubation at $4{ }^{\circ} \mathrm{C}$, the adsorbed proteins were washed three times in lysis buffer and resuspended in $40 \mu \mathrm{l} \beta$-glycerophosphate (50 mM, pH 7.2), $0.1 \mathrm{mM}$ sodium vanadate, $10 \mathrm{mM} \mathrm{MgCl}_{2}, 100 \mu \mathrm{M} \gamma\left[{ }^{32} \mathrm{P}\right] \mathrm{ATP}$ $(5,000 \mathrm{cpm} / \mathrm{pmol}), 50 \mu \mathrm{g} / \mathrm{ml}$ IP-20 (TTYADFIASGRTGRRNAIHD), and $200 \mu \mathrm{M}$ EGF-R peptide (RRELVEPLTPSGEAPQALLR). The reactions were incubated for 20 minutes at $30^{\circ} \mathrm{C}$, then stopped by the addition of 10 $\mu \mathrm{l}$ of $25 \%$ trichloroacetic acid. EGF-R peptide phosphorylation was assessed by phosphocellulose filter binding as described (28). PD98059 (100 $\mu \mathrm{M})$, an inhibitor of MEK-1 (the upstream activator of ERK), was added in selected experiments.

For measurement of p38 MAP kinase activity, cultured cells were homogenized as above, and lysates were heated in a boiling water bath after addition of SDS sample buffer. Then $50 \mu \mathrm{g}$ of protein was loaded per 
lane on either a $10 \%$ or a $12.5 \%$ polyacrylamide gel and subjected to SDS-PAGE. Proteins were transferred to either Immobilon or NitroPlus (Micron Separations Inc., Westboro, Massachusetts, USA), and the blot was blocked with 5\% BSA, Fraction V (AMRESCO Inc., Solon, Ohio, USA) in Tris-buffered saline ( $\mathrm{pH} 8$ ) plus $0.1 \%$ Tween 80 for 2 hours at room temperature. Antisera incubation was done at $4^{\circ} \mathrm{C}$ for 16 hours in $5 \%$ BSA/Tween 80/TBS, after which the membrane was washed with Tween 80/TBS. Secondary antisera conjugated to horseradish peroxidase were incubated with the membrane for 2 hours at room temperature in 5\% BSA/Tween 80/TBS, followed by washes as above and incubation with chemiluminescent substrate. An antibody specific for the activated (phosphorylated at Thr180 and Tyr-182) form of p38 MAP kinase, and a control antibody that does not distinguish between phospho- and dephosphorylated p38 MAP kinase, were obtained from New England Biolabs Inc. (Beverly, Massachusetts, USA). Intensity of bands on Western blot films was determined by scanning with a video image scanner and digitizing software.

Reagents. PD98059 (100 M; Parke-Davis, Ann Arbor, Michigan, USA) was used as an inhibitor of MEK-1, the upstream activator of ERK (29). SB203580 (500 nM to 1 $\mu \mathrm{M}$; Calbiochem-Novabiochem, La Jolla, California, USA) was used as an inhibitor of p38 $(30,31)$. In separate patch-clamp studies, recombinant p $38 \alpha$ and MEK-6 were delivered to the cell interior by inclusion in the patch pipette (32). EGTA (5 mM) and amiloride (100 $\mu \mathrm{M})$ were used in selected patch-clamp experiments.

Statistics. Results are presented as mean \pm SEM, with $n$ representing the number of cells used for patchclamp studies and the number of culture plates or repetitions for other assays. The Student paired or unpaired $t$ test was used to assess statistical significance as indicated, and $P$ values $<0.05$ were considered to be statistically significant.

\section{Results}

Cell volume increases are mediated by channel-mediated $\mathrm{Na}^{+}$ influx. Exposure of cells to hypertonic buffer (40\% increase in $\mathrm{NaCl}, \sim 395 \mathrm{mOsm}$ ) caused a rapid initial decrease in relative volume to $0.85 \pm 0.01(n=6$, $P<0.001$ compared with isotonic conditions) within 3 minutes. The decrease was followed by gradual recovery toward basal values (RVI) despite continued exposure to hypertonic buffer $(0.94 \pm 0.01$ at 30 minutes; Figure 1$)$. Volume recovery was inhibited $(0.79 \pm 0.02$ at 30 minutes, $P<0.001$ ) when $\mathrm{Na}^{+}$in the bath solution was replaced with the impermeant ion $\mathrm{Tris}^{+}$, indicating that volume recovery is mediated by $\mathrm{Na}^{+}$influx.

To determine if $\mathrm{Na}^{+}$influx is mediated by a conductive pathway, parallel whole-cell patch-clamp studies were performed. With the standard bath and pipette solutions, the reversal potential for $\mathrm{Na}^{+}$ions $\left(\mathrm{E}_{\mathrm{Na}+}\right)$ is $+66 \mathrm{mV}$, and the reversal potential for cations $\left(\mathrm{E}_{\mathrm{cat}}\right)$ is $0 \mathrm{mV}$. Consequently, the opening of a $\mathrm{Na}^{+}$-selective conductance would result in inward currents at both $0 \mathrm{mV}$ and -80
$\mathrm{mV}$, and the opening of an NSC conductance would result in inward currents at $-80 \mathrm{mV}$ but not at $0 \mathrm{mV}\left(\mathrm{E}_{\mathrm{cat}}\right)$.

Under basal conditions, currents were small (less than $-3.0 \pm 1.1 \mathrm{pA} / \mathrm{pF}$ at $-80 \mathrm{mV})$. Exposure to hypertonic buffer (20 mM sucrose, $\sim 320 \mathrm{mOsm}$ ) resulted in activation of inward currents within 2-3 minutes (representative trace shown in Figure 2a), increasing current density more than 30 -fold, from $-2.1 \pm 0.3 \mathrm{pA} / \mathrm{pF}$ to $-69.5 \pm 11.2 \mathrm{pA} / \mathrm{pF}$ at $-80 \mathrm{mV}(P<0.001, n=20)$. Hypertonic-induced currents displayed a linear I-V relationship between -120 and $+100 \mathrm{mV}$, and a reversal potential near $0 \mathrm{mV}$ (Figure $2 \mathrm{~b}$ ). Because currents at $-80 \mathrm{mV}$ could be due to either $\mathrm{Cl}^{-}$or NSC conductance, several additional studies were performed to determine the permeability of the hypertonically stimulated conductance. First, the amplitude and reversal potential were unaffected by substitution of bath $\mathrm{Na}^{+}$ with $\mathrm{K}^{+}(-58.6 \pm 13.1 \mathrm{pA} / \mathrm{pF}, n=4$; Figure $2 \mathrm{~b})$. Second, the $\mathrm{Cl}^{-}$channel blocker 5-nitro-2-(3-phenylpropylamine)benzoic acid (NPPB) had little effect on the magnitude of the currents at $-80 \mathrm{mV}(-55.4 \pm 14.2$, $n=4)$. Third, partial replacement of extracellular $\mathrm{Na}^{+}$ with Tris $^{+}$reduced inward currents and caused a negative shift in the reversal potential (Figure 2, b-d). Decreasing extracellular $\left[\mathrm{Na}^{+}\right]$to $40 \mathrm{mM}$ decreased the magnitude of the inward currents $(-160 \pm 35.8 \mathrm{pA}$, $n=5, P<0.001$; Figure 2c) measured at $-80 \mathrm{mV}$ and shifted the reversal potential to $-26.6 \pm 2.3 \mathrm{mV}$ (Figure 2d) compared with control (-781.1 \pm 71.7 inward current $\mathrm{pA}, n=9$; reversal potential $+0.5 \pm 0.01 \mathrm{mV}$ ). Decreasing extracellular $\left[\mathrm{Na}^{+}\right]$to $20 \mathrm{mM}$ decreased the magnitude of inward currents further (to $-53.4 \pm 6.17$ $\mathrm{pA}, n=4, P<0.001)$, and shifted the reversal potential in a more negative direction (to $-41.3 \pm 3.8 \mathrm{mV}$ ). It should be noted that while substitution with Tris $^{+}$

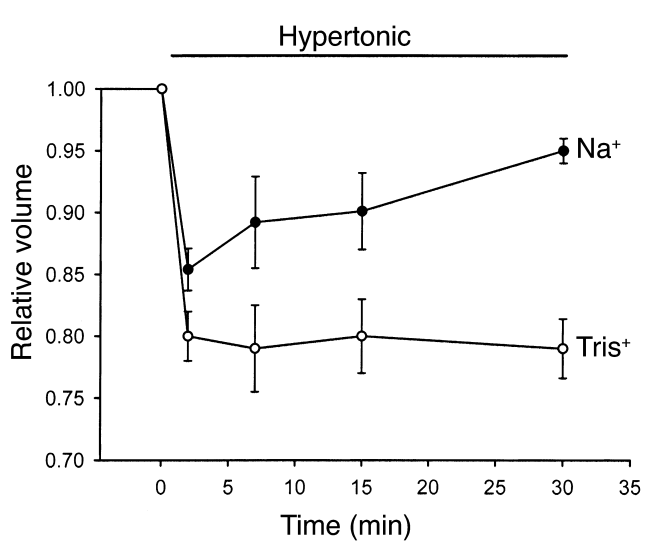

\section{Figure 1}

Cell volume recovery is $\mathrm{Na}^{+}$dependent. HTC cell suspensions were exposed to hypertonic buffer ( $40 \%$ increase in $\mathrm{NaCl}, \sim 395 \mathrm{mOsm}$ ) at time 0 , and cell volume (20,000 cells for each timepoint) was measured with a Coulter Multisizer. Hypertonic exposure resulted in a rapid initial decrease in cell volume, followed by gradual recovery toward basal values. When $\mathrm{Na}^{+}$in the buffer solution was replaced with the impermeant cation $\mathrm{Tris}^{+}$, volume recovery was inhibited. Values represent mean \pm SEM for four trials, with 20,000 cells for each timepoint. 

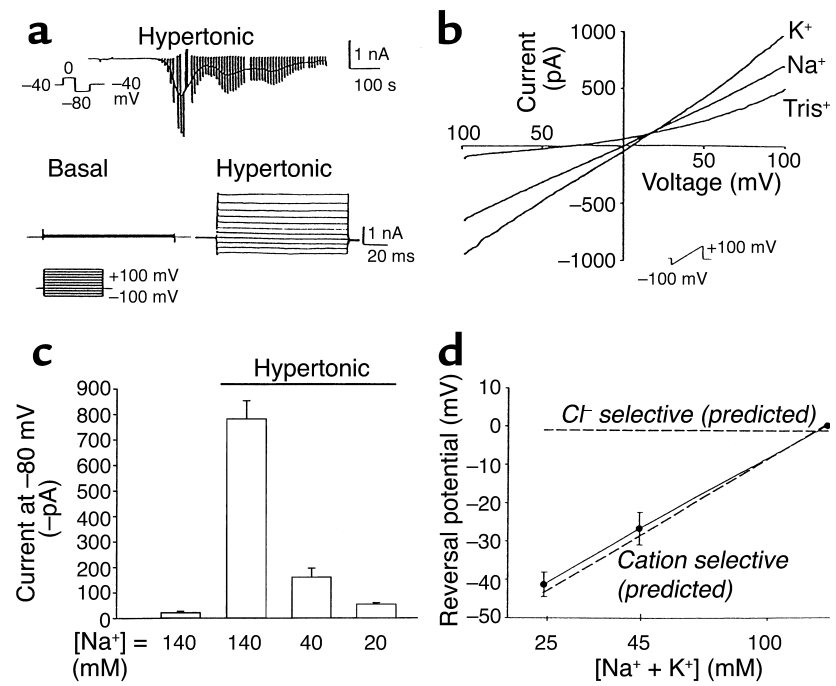

\section{Figure 2}

Hypertonic exposure activates NSC currents. (a) Representative whole-cell recording. Currents at $-80 \mathrm{mV}$ (downward deflection of the current tracing) correspond to $I_{\mathrm{Na}^{+}}$(see Methods). Hypertonic exposure (sucrose $20 \mathrm{mM}, \sim 320 \mathrm{mOsm}$ ) resulted in activation of inward currents (top tracing). A voltage-step protocol (test potentials between $-100 \mathrm{mV}$ and $+100 \mathrm{mV}$ in $20-\mathrm{mV}$ increments) was used to measure basal and hypertonic-induced currents (bottom tracings). (b) I-V relationship of whole-cell currents. Currents induced by hypertonic exposure were measured utilizing a voltage-ramp protocol $(-100$ $\mathrm{mV}$ to $+100 \mathrm{mV}$ over $200 \mathrm{~ms}$ ). Hypertonicity increased current amplitude with either $\mathrm{Na}^{+}$or $\mathrm{K}^{+}$as the primary extracellular cation, characterized by reversal near $0 \mathrm{mV}$. When $\mathrm{Na}^{+}$in the extracellular solution was partially replaced with the impermeant cation Tris ${ }^{+}$(final $\left[\mathrm{Na}^{+}\right]$, $40 \mathrm{mM}$ ), there was a significant decrease in inward current amplitude, and a shift in reversal potential to $-26.6 \pm 2.3 \mathrm{mV}(n=4)$, as expected for a cation-selective channel. (c) Decreasing $\left[\mathrm{Na}^{+}\right]$in the extracellular solution by partial replacement with the impermeant cation Tris $^{+}$resulted in a significant decrease in the magnitude of the inward currents measured at $-80 \mathrm{mV}$. (d) Decreasing $\left[\mathrm{Na}^{+}+\mathrm{K}^{+}\right]$, by replacement with Tris $^{+}$, resulted in a shift in reversal potential consistent with the predicted reversal potential for a cation-selective conductance (shown by dotted line). The expected reversal potential for a primary $\mathrm{Cl}^{-}$conductance is shown by the dotted line at top.

decreased inward currents as expected for a cationselective channel, Tris ${ }^{+}$also decreased the magnitude of outward currents measured at positive voltage potentials (Figure $2 \mathrm{~b}$ ), suggesting that Tris $^{+}$may also display nonspecific channel-blocking properties. The shift in reversal potential at the different extracellular cation concentrations is shown in Figure $2 \mathrm{~d}$. As shown, the findings are consistent with the reversal potential predicted by the Goldman-Hodgkin-Katz equation for a primary cation conductance (dotted line). The predicted reversal potential for a primary $\mathrm{Cl}^{-}$ conductance is shown for comparison. Taken together, these findings are consistent with volume-sensitive $\mathrm{Na}^{+}$influx through opening of an NSC channel with approximately equal $\mathrm{Na}^{+}$and $\mathrm{K}^{+}$permeability.

HTC cells have previously been shown to express an NSC conductance that displays $\mathrm{Ca}^{2+}$-dependent opening $(18,20)$. To determine if this hypertonically stimu- lated cation conductance is $\mathrm{Ca}^{2+}$ dependent, separate experiments were performed with low intracellular $\left[\mathrm{Ca}^{2+}\right]$. Increasing EGTA $\left(5 \mathrm{mM}\right.$, no added $\left.\mathrm{Ca}^{2+}\right)$ in the pipette solution inhibited current activation by hypertonic exposure $(-8.1 \pm 2.8 \mathrm{pA} / \mathrm{pF}, n=5, P<0.001$; see Figure 5 , solid bars) compared with control conditions (free $\left[\mathrm{Ca}^{2+}\right] \sim 100 \mathrm{nM},-69.5 \pm 11.2 \mathrm{pA} / \mathrm{pF}, n=20$ ). Previous studies of primary rat hepatocytes indicated that RVI following hypertonic exposure is mediated by an amiloride-sensitive $\mathrm{Na}^{+}$conductance $(16,33)$. To determine whether the hypertonically stimulated conductance in HTC cells displays similar properties, studies were performed in the presence or absence of the $\mathrm{Na}^{+}$ channel inhibitor amiloride $(100 \mu \mathrm{M})$. Amiloride inhibited hypertonically stimulated ( $50 \mathrm{mM}$ sucrose) currents by approximately $68 \%(-37.7 \pm 5.8 \mathrm{pA} / \mathrm{pF}, n=5$, $P<0.01)$ compared with control $(-116.9 \pm 17.8 \mathrm{pA} / \mathrm{pF}$, $n=9$; see Figure 5, solid bars).

Osmolarity-sensitive changes in MAP kinase activity. To evaluate the effects of HTC cell size on MAP kinase activity, cells were exposed to hypertonic (500 mOsm) or hypotonic (100 mOsm) conditions for 5 minutes, and kinase activity was assessed. Representative measurements of p38 MAP kinase are shown in Figure 3a; summary data for all kinases are shown in Figure 3b. Under isotonic conditions, there was detectable constitutive activity of p38, JNK, and ERK kinases. Decreases in cell volume caused by hypertonic exposure increase in both ERK (fivefold) and JNK (fourfold) activity, but had little effect on p38 MAP kinase activity. In separate studies, the MEK-1 inhibitor PD98059 $(100 \mu \mathrm{M})$ inhibited both basal (by $65.5 \% \pm 10.1 \%$ ) and hypertonically induced (by $86.1 \% \pm 15.5 \%$ ) ERK activity (data not shown).

In contrast, increases in cell volume caused by hypotonic exposure resulted in a large increase in p38 MAP kinase activity (tenfold), but had little effect on ERK or JNK activity compared with isotonic conditions. The putative p38 MAP kinase inhibitor SB203580 $(1 \mu \mathrm{M})$ did not effect ERK or JNK activity, but completely inhibited both constitutive and volume-sensitive p38 MAP kinase activity (Figure 3 ). These studies demonstrate that (a) there is constitutive ERK, JNK, and p38 MAP kinase activity under basal (isotonic) conditions; (b) increases in cell volume (hypotonic exposure) increase p38 activity; and (c) there is differential regulation of P38 MAP kinase activity versus ERK and JNK activity in response to changes in HTC cell volume.

$\mathrm{Na}^{+}$permeability is not influenced by ERK activity. Given the large increase in ERK activity with hypertonic exposure, the potential role of ERK in NSC channel regulation was evaluated. If ERK modulates volume-sensitive membrane $\mathrm{Na}^{+}$permeability through MEK- 1 activation, inhibition of MEK-1 would be expected to prevent channel opening. To test this hypothesis, whole-cell patch-clamp experiments were performed in the presence or absence of PD98059 $(100 \mu \mathrm{M})$, an inhibitor of MEK-1. In control cells, exposure to hypertonic buffer (50 $\mathrm{mM}$ sucrose, $\sim 350 \mathrm{mOsm}$ ) resulted in characteristic increases in $\mathrm{Na}^{+}$permeability $(-86.1 \pm 14.2 \mathrm{pA} / \mathrm{pF}$, 
$n=6)$, and the response was unchanged in the presence of PD98059 $(-68.9 \pm 9.3 \mathrm{pA} / \mathrm{pF}, n=5$, data not shown). Thus, volume-sensitive increases in ERK activity are not likely to be involved in the regulation of $\mathrm{Na}^{+}$influx.

Inhibition of $p 38$ increases membrane $\mathrm{Na}^{+}$permeability. Since there did not appear to be a direct effect of ERK on channel regulation, the alternative possibility that p38 MAP kinase has an inhibitory role in channel regulation was explored by measuring membrane $\mathrm{Na}^{+}$permeability under basal conditions and during inhibition of p38 (Figure 4). Whole-cell currents were small in control cells $(-2.1 \pm 0.3 \mathrm{pA} / \mathrm{pF}, n=15)$. However, exposure to the p38 MAP kinase inhibitor SB203580 (500 nM) was followed by an increase in membrane $\mathrm{Na}^{+}$permeability in the absence of a volume challenge $(-62.7 \pm 8.1$ $\mathrm{pA} / \mathrm{pF}, n=15, P<0.001$; Figure 4, a-c). The SB203580activated current appeared identical to that activated by hypertonic exposure, with a linear I-V relationship, and reversal near $0 \mathrm{mV}$ (Figure 4, a and d). Substitution of extracellular $\mathrm{Na}^{+}$with $\mathrm{K}^{+}$did not affect current amplitude $(-69.4 \pm 12.5 \mathrm{pA} / \mathrm{pF}, n=4)$; nor did exposure to the $\mathrm{Cl}^{-}$channel inhibitor NPPB $(-43.6 \pm 10.8 \mathrm{pA} / \mathrm{pF}, n=4$, $P>0.05)$. However, partial substitution of bath $\mathrm{Na}^{+}$with Tris $^{+}$significantly inhibited inward current amplitude (measured at $-80 \mathrm{mV}$ ) and shifted the reversal potential in a negative direction (inward current, $-340.1 \pm 56.5$ $\mathrm{pA}$, and reversal potential, $-25.3 \pm 2.6 \mathrm{mV}$, at $\left[\mathrm{Na}^{+}\right]=40$ $\mathrm{mM}, n=5, P<0.001$; and inward current, $-168.2 \pm 14.8$ $\mathrm{pA}$, and reversal potential, $-40.5 \pm 4.2 \mathrm{mV}$ at $\left[\mathrm{Na}^{+}\right]=20$ $\mathrm{mM}, n=4, P<0.001)$ compared with control $\left(\left[\mathrm{Na}^{+}\right]=\right.$ $140 \mathrm{mM},-941.2 \pm 84.5 \mathrm{pA}$ inward current, and $0 \pm 0.1$ $\mathrm{mV}$ reverse potential, $n=9$ ).

The SB203580-activated currents also exhibited similar regulatory properties, in that (a) inclusion of EGTA (5 $\mathrm{mmol} / \mathrm{l}$, no added $\left.\mathrm{Ca}^{2+}\right)$ in the patch pipette abolished the response $(-8.5 \pm 2.1 \mathrm{pA} / \mathrm{pF}, n=5, P<0.01$; Figure 5,

\footnotetext{
Figure 3

Osmolarity-sensitive changes in MAP kinase activity. HTC cells were exposed to isotonic ( 300 mOsm), hypotonic ( 100 mOsm), or hypertonic ( $\sim 500 \mathrm{mOsm})$ buffer solutions for 5 minutes, then immediately homogenized in lysis buffer. (a) Cell lysates were subjected to SDS-PAGE and Western blot analysis with either an antibody specific for the activated (phosphorylated at Thr-180 and Tyr-182) form of p38 (phospho-p38) or a control antibody that does not distinguish between phospho- and dephosphorylated p38 MAP kinase (total p38). Constitutive phospho-p38 activity was observed under isotonic conditions; values increased with hypotonic exposure. Activity was inhibited by the p38 inhibitor SB203580 ( $1 \mu \mathrm{M})$, but not by the tyrosine kinase inhibitor genistein $(10 \mu \mathrm{M})$. None of the various exposures resulted in changes in total p38. (b) Average MAP kinase activity in response to osmotic changes performed as described in Methods. Under isotonic conditions, there was constitutive activity of p38, JNK, and ERK kinases. Hypertonic exposure stimulated a large increase in both ERK (fivefold) and JNK (fourfold) activity, but had little effect on p38 MAP kinase activity. In contrast, hypotonic exposure resulted in a large increase in p38 MAP kinase activity (tenfold), but had little effect on ERK or JNK activity compared with isotonic conditions. The putative p38 MAP kinase inhibitor SB203580 did not affect ERK or JNK activity, but completely inhibited constitutive P38 MAP kinase activity.
}

open bars), and (b) exposure to amiloride $(100 \mu \mathrm{M})$ inhibited currents by approximately $61 \%(-38.36 \pm 10.8 \mathrm{pA} / \mathrm{pF}$, $n=4)$ compared with control cells $(-99.54 \pm 6.55 \mathrm{pA} / \mathrm{pF}$, $n=10, P<0.001$; Figure 5, open bars). Lastly, the hypertonic-induced and SB203580-activated currents were not additive. When currents were first activated by hypertonic exposure (50 mM sucrose, $-69.5 \pm 11.2 \mathrm{pA} / \mathrm{pF}, n=6)$ there was no further increase caused by exposure to SB203580 (500 nM, $-70.73 \pm 7.65 \mathrm{pA} / \mathrm{pF}, n=6$; Figure 4, a and c). Taken together, these findings indicate that currents activated by SB203580 are not distinguishable from currents activated by hypertonic exposure, and suggest an important regulatory role for p38 MAP kinase in inhibition of volume-sensitive $\mathrm{Na}^{+}$permeability.

Inhibition of $p 38$ activity increases cell size. Since inhibition of $\mathrm{p} 38$ increases membrane $\mathrm{Na}^{+}$permeability, the resulting influx of $\mathrm{Na}^{+}$would be expected to increase cell volume. To assess this directly, cell volume was measured in the presence or absence of $\mathrm{p} 38$ inhibition (Figure 6). Compared with control, acute inhibition of p38 with SB203580 (500 nM) resulted in a rapid initial increase in cell size $(5.8 \% \pm 0.1 \%, n=5, P<0.01)$,
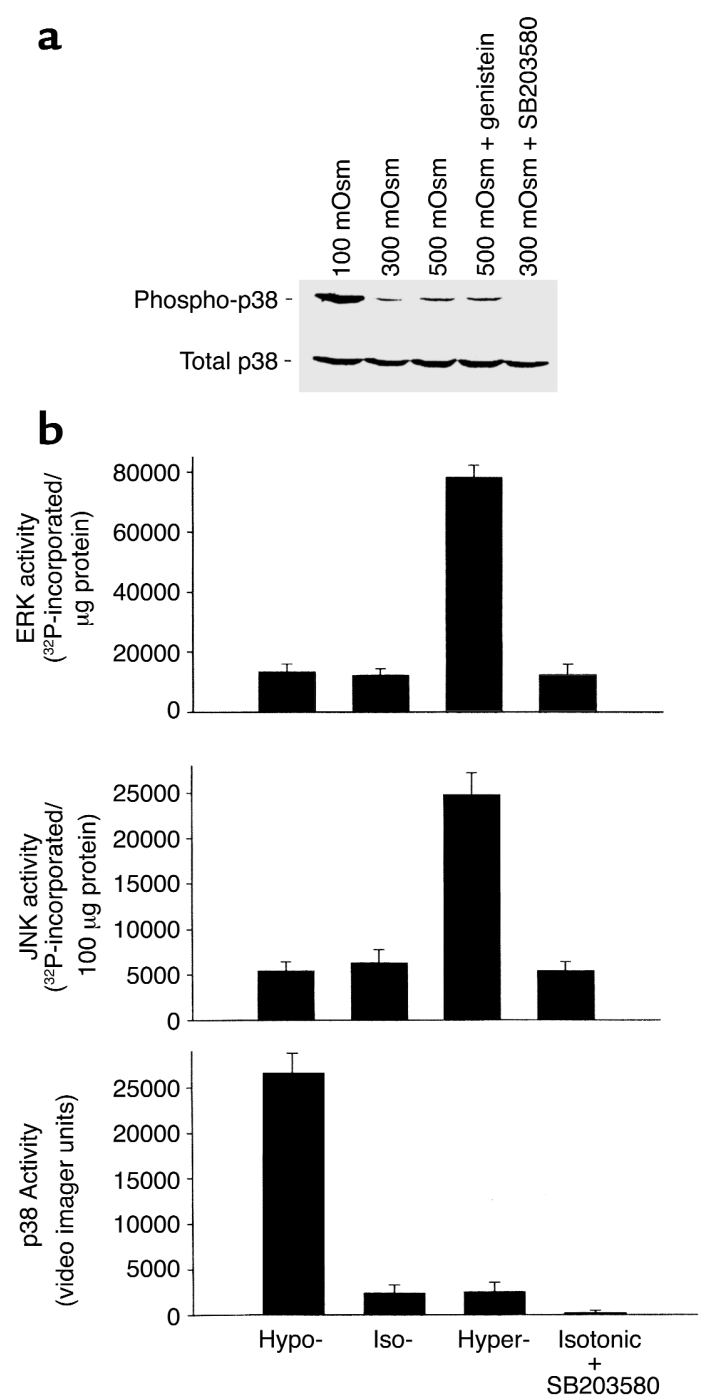


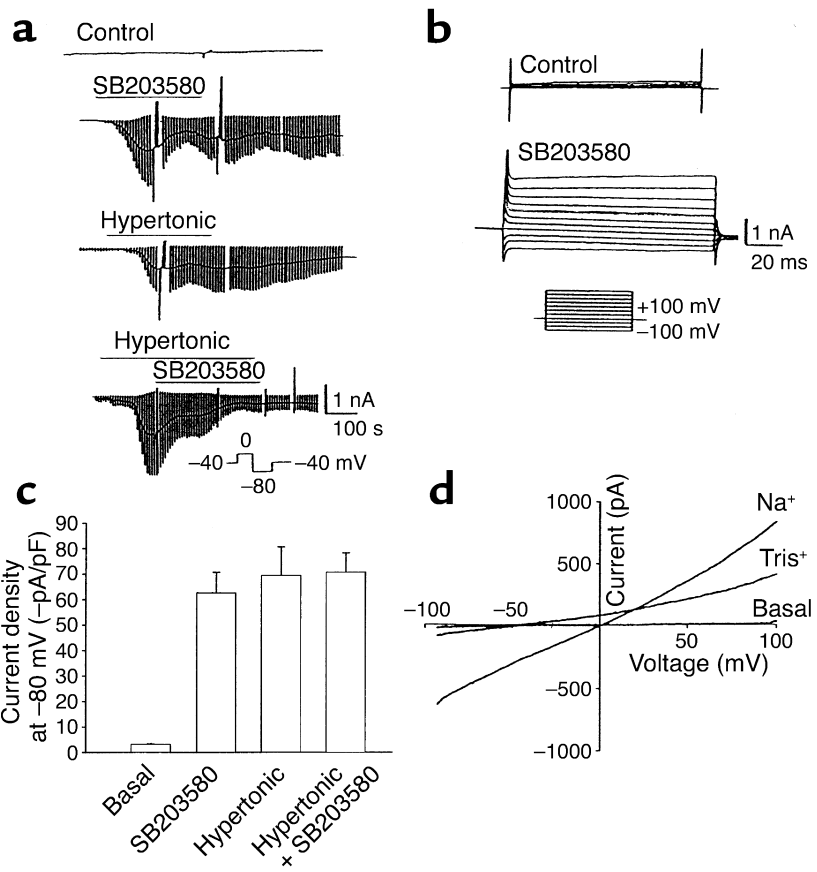

reaching a maximum at 5 minutes. This was followed by a gradual return to basal values by 30 minutes. This gradual decrease in cell size likely represents an adaptive response to cell swelling, as previously described in these and other cell types $(25,34)$. Thus, constitutive activity of $\mathrm{p} 38$ serves an important role in the maintenance of cell volume and membrane $\mathrm{Na}^{+}$ permeability under isotonic conditions.

Intracellular dialysis with purified $\$ 38$ MAP kinase inhibits channel opening. Since kinase inhibition can have unanticipated effects on other regulatory pathways, an alternate strategy was used to assess the relationship between p38 MAP kinase and $\mathrm{Na}^{+}$permeability. p38 $\alpha$ is activated by dual phosphorylation of adjacent tyrosine and threonine residues by the upstream MAP kinase kinase, MEK-6 (35-37). To determine if activated p38 $\alpha$ MAP kinase inhibits channel function, the purified kinases p38 $\alpha(5 \mu \mathrm{g} / \mathrm{ml})$ and MEK-6 $(5 \mu \mathrm{g} / \mathrm{ml})$ were delivered, individually or together, to the cell interior by inclusion in the patch pipette. There was no effect by p38 $\alpha$ and MEK- 6 together on basal currents measured under isotonic conditions (Figure 7 , a and b). In control cells dialyzed with heat-inactivated $\left(100^{\circ} \mathrm{C}\right.$, 30 minutes) p38 $\alpha$ and MEK-6, hypertonic exposure (20 $\mathrm{mM}$ sucrose, $\sim 320 \mathrm{mOsm}$; Figure 7) resulted in characteristic current activation $(-62.5 \pm 18.7 \mathrm{pA} / \mathrm{pF}, n=5)$. Dialysis with either $\mathrm{p} 38 \alpha$ or MEK- 6 individually resulted in partial inhibition $(-40.1 \pm 8.2 \mathrm{pA} / \mathrm{pF}$ and $-46.8 \pm 10.3 \mathrm{pA} / \mathrm{pF}, n=4$, respectively; Figure 7 , values not statistically significant compared with control). However, dialysis with p $38 \alpha$ and MEK- 6 together resulted in significant inhibition of the response to hypertonic exposure $(-10.4 \pm 3.5 \mathrm{pA} / \mathrm{pF}, n=6, P<0.01$; Figure 7 , $a$ and $b$ ). To assess whether the inhibitory effects of recombinant p38 $\alpha+$ MEK- 6 were detected

\section{Figure 4}

Inhibition of p38 MAP kinase increases membrane $\mathrm{Na}^{+}$permeability. Whole-cell currents were measured under basal conditions and during exposure to the p38 inhibitor SB203580 (500 nM). (a) Representative whole-cell recordings. Currents at $-80 \mathrm{mV}$ (downward deflection of the current trace) correspond to $/_{\mathrm{Na}^{+}}$. Under basal conditions, currents were small (first tracing). Exposure to SB203580 stimulated an increase in currents (second tracing) with properties similar to those activated by hypertonic exposure ( $20 \mathrm{mM}$ sucrose, third tracing). Exposure to SB203580 did not further increase current magnitude after cells were first exposed to hypertonicity ( $50 \mathrm{mM}$ sucrose, $\sim 350 \mathrm{mOsm}$ ) to maximally activate currents (fourth tracing). (b) Voltage-step protocol (as described in Figure 2a) demonstrating currents under control conditions and following exposure to SB203580 (500 $\mathrm{nM})$. (c) Cumulative data recorded as average current density at -80 $\mathrm{mV}$. Both SB203580 (500 nM) and hypertonicity (50 mM sucrose) resulted in large increases in inward currents. The responses were not additive. (d) I-V relationship of whole-cell currents measured under basal conditions and during exposure to SB203580. With $\mathrm{Na}^{+}$as the primary extracellular cation, currents were characterized by a nearly linear I-V relationship and reversal near $0 \mathrm{mV}$. Partial replacement of $\mathrm{Na}^{+}$with Tris ${ }^{+}$(final $\left[\mathrm{Na}^{+}\right]=20 \mathrm{mM}$ ) decreased inward currents and shifted the reversal potential to $-40.5 \pm 4.2 \mathrm{mV}$, as expected for a cation-selective conductance.

over a broader range of osmotic challenge, cells were exposed to graded increases in osmolarity (Figure 7c). Under control conditions, the current amplitude increased with increasing transmembrane osmolar gradients. In the presence of intracellular p38 $\alpha$ + MEK-6, there was significant inhibition of current amplitude at lower transmembrane osmolar gradients $(10 \mathrm{mM}$ and $20 \mathrm{mM}$ sucrose, $P<0.01$ ). The inhibitory effect of p38 $\alpha$ + MEK- 6 was overcome at higher transmembrane osmolar gradients (50 mM sucrose, $P>0.05$ compared with control at $50 \mathrm{mM}$ sucrose).

\section{Discussion}

Environmental signals such as ultraviolet radiation, heat shock, and osmotic stress cause p38 MAP kinase activation in several cell types $(4,7,8)$. While many of

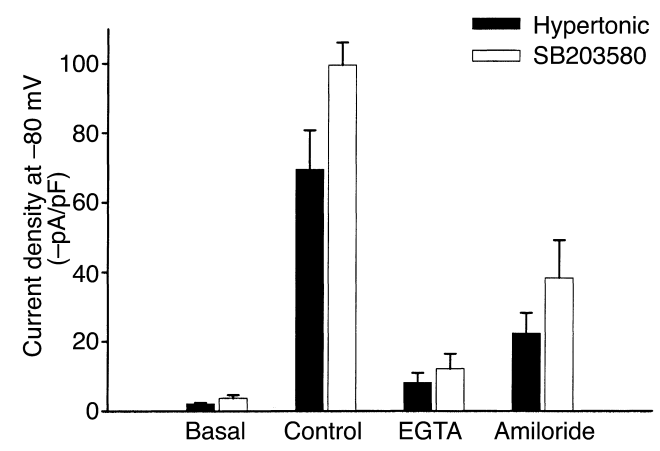

Figure 5

Comparison of hypertonic- and SB203580-induced currents. Average current density for currents activated by hypertonic exposure $(20 \mathrm{mM}$ sucrose) or SB203580 (500 nM) was measured at $-80 \mathrm{mV}$. Both hypertonic- and SB203580-induced currents were inhibited by inclusion of EGTA ( $5 \mathrm{mM}$, no added $\left.\mathrm{Ca}^{2+}\right)$ in the patch pipette solution, and by amiloride $(100 \mu \mathrm{M})$ in the extracellular solution $(P<0.01)$. 


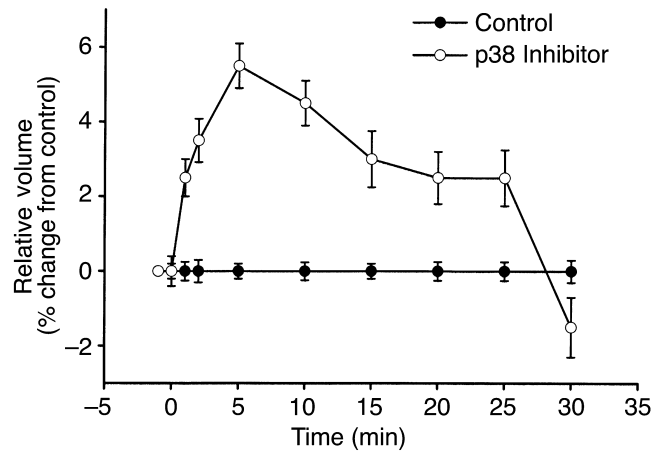

Figure 6

Inhibition of 38 increases cell volume. Cell volume was measured in the presence or absence of $\mathrm{p} 38$ inhibitor using a Coulter Multisizer. Compared with control, acute inhibition of p38 with SB203580 (500 $\mathrm{nM})$ resulted in a rapid initial increase in cell size $(5.8 \pm 0.1 \%, n=5$, $P<0.01)$, reaching a maximum at 5 minutes. This was followed by a gradual return to basal values by 30 minutes.

the physiologic effects of p38 are mediated by transcriptional regulation, there is increasing evidence that p38 can interact with and modulate other cytoplasmic and membrane proteins in a phosphorylation-dependent manner. In these studies of HTC cells, observations using a variety of techniques support a broader role for $\mathrm{p} 38 \mathrm{MAP}$ kinase as an early and important signal in coordinating changes in cell volume and membrane $\mathrm{Na}^{+}$permeability.

The principal findings of these studies are that (a) there is constitutive activity of p38 MAP kinase under basal (isotonic) conditions; (b) inhibition of constitutive p38 MAP kinase results in increased membrane $\mathrm{Na}^{+}$permeability and increases in cell volume; (c) intracellular dialysis with purified $\mathrm{p} 38 \alpha$, and its upstream

\section{Figure 7}

Intracellular dialysis with recombinant p38 MAP kinase protein inhibits volume-sensitive current activation. Under whole-cell patchclamp conditions, the recombinant kinases $\mathrm{p} 38 \alpha(5 \mu \mathrm{g} / \mathrm{ml})$ and MEK-6 $(5 \mu \mathrm{g} / \mathrm{ml})$ were delivered, individually or together, to the cell interior by inclusion in the patch pipette, and cells were then exposed to hypertonic buffer ( $20 \mathrm{mM}$ sucrose, $\sim 320 \mathrm{mOsm}$ ). (a) Whole-cell currents measured using the voltage-step protocol (as described in Figure 2a). Currents were small with intracellular dialysis of $\mathrm{p} 38 \alpha$ and MEK-6 under isotonic conditions (top tracing). However, $\mathrm{p} 38 \alpha$ and MEK-6 significantly inhibit the amplitude of hypertonic-induced currents (bottom tracing) as compared with control (middle tracing). (b) Cumulative data expressed as average current density at $-80 \mathrm{mV}$. Control cells, dialyzed with heat-inactivated p38 $\alpha$ and MEK-6, demonstrated characteristic current activation. Dialysis with either p $38 \alpha$ or MEK- 6 individually resulted in partial inhibition, which was not statistically significant compared with control. However, dialysis with p $38 \alpha$ and MEK- 6 together resulted in significant current inhibition. There was no effect of $p 38 \alpha$ and MEK- 6 on basal (isotonic) currents. (c) Under control conditions, current density increased with increasing transmembrane osmolar gradients. In the presence of intracellular $p 38 \alpha+$ MEK-6, there was significant inhibition of current amplitude at lower transmembrane osmolar gradients (5-20 $\mathrm{mM}$ sucrose). However, this inhibitory effect was overcome at higher transmembrane osmolar gradients (50 mM sucrose). ${ }^{*} P<0.01$. activator MEK-6, inhibits volume-sensitive channel opening; and (d) exposure to hypotonicity to increase cell volume results in large increases in p38 activity. Collectively, these findings suggest that p38 MAP kinase plays an important regulatory role governing membrane $\mathrm{Na}^{+}$permeability and cell volume regulation through inhibitory effects on NSC channels.

Previous biophysical studies have identified NSC channels in liver cells that are regulated in part by cytosolic $\left[\mathrm{Ca}^{2+}\right](18,20)$. While channel proteins are abundant, with approximately 2,000 channels/cell, they are generally closed under basal conditions. Channels open in response to vasopressin or other agents known to mobilize $\mathrm{Ca}^{2+}(23)$, and in response to cell shrinkage induced by osmotic (17) or oxidative stress (20). The resulting influx of $\mathrm{Na}^{+}$favors water movement into the cell and restoration of cell volume toward basal values. Interestingly, p38 MAP kinase is known to be constitutively active in hepatocytes, and its activity is selectively decreased during oxidative stress (38), consistent with a potential role as an inhibitor of $\mathrm{Na}^{+}$influx.

a

Isotonic + p38- $\alpha / \mathrm{MEK}-6$

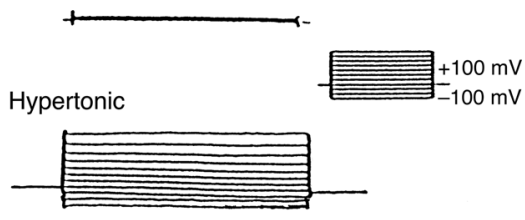

Hypertonic + p38- $\alpha /$ MEK-6
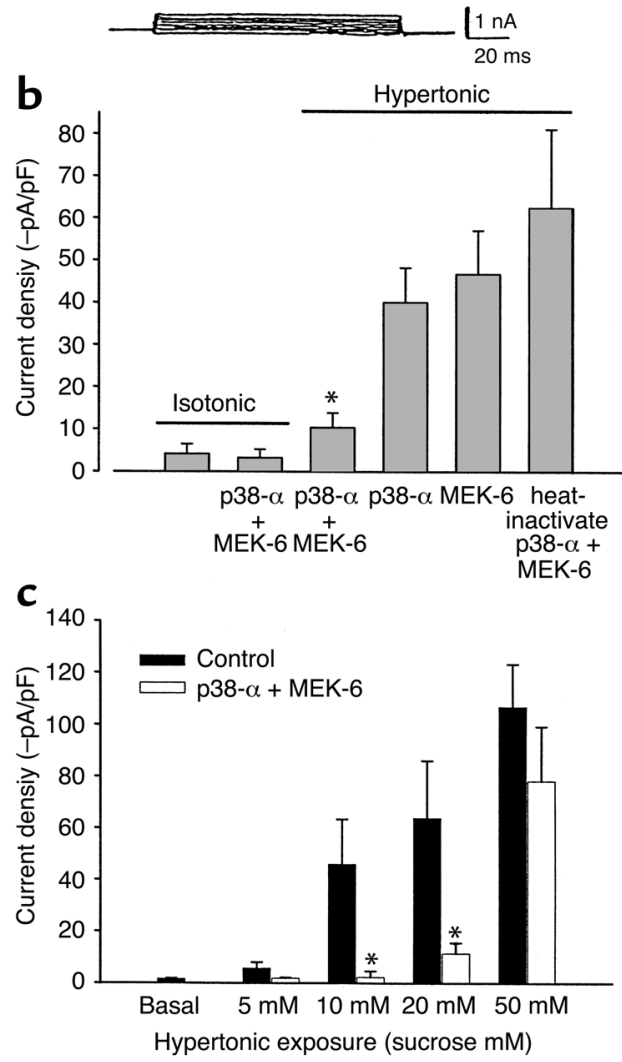
These studies provide further evidence that NSC channels are crucial to the maintenance of cell volume and RVI in hepatocytes. The conductance is characterized by equal permeability for $\mathrm{Na}^{+}$and $\mathrm{K}^{+}$and a linear $\mathrm{I}-\mathrm{V}$ relationship, and shows no time dependence. Partial substitution of extracellular $\mathrm{Na}^{+}$with Tris $^{+}$causes a decrease in inward currents and a negative shift in reversal potential, as anticipated for an NSC conductance. It should be noted, however, that a slight decrease in the amplitude of outward currents was also observed with Tris ${ }^{+}$substitution. The possibility that $\mathrm{Tris}^{+}$is also a partial channel blocker, or has other nonspecific effects on cell volume, intracellular $\mathrm{pH}$, or other parameters that may affect channel open probability cannot be excluded.

The partial inhibition of volume-sensitive conductance by amiloride is consistent with previous studies of rat hepatocytes (16). Previous reports in other cell types have demonstrated variable effects of amiloride on NSC currents (39-42). This variability may reflect different channel types; the molecular identity of NSC channels in liver cells has not been defined. The basic biophysical properties of the NSC channels described here appear similar to cyclic nucleotide-gated channels described in other cell types $(43,44)$ that demonstrate amiloride sensitivity (45-47). The finding that amiloride only partially inhibits NSC conductance has several potential explanations. First, amiloride sensitivity may be modulated by $\left[\mathrm{Ca}^{2+}\right](39,48)$, mechanical stress (49), or other factors. Alternatively, more than one $\mathrm{Na}^{+}$channel type may contribute to volume-regulated $\mathrm{Na}^{+}$influx. In fact, the epithelial $\mathrm{Na}^{+}$channel $(\mathrm{ENaC})$, which is also inhibited by amiloride, has recently been implicated in volume-stimulated $\mathrm{Na}^{+}$ influx in rat hepatocytes (33). However, the NSC conductance of HTC cells does not exhibit the pore or regulatory properties anticipated for $\mathrm{ENaC}$. Thus, it will be important to define the molecular mechanisms responsible for volume-sensitive $\mathrm{Na}^{+}$influx, and assess the specific regulatory pathways involved for each.

Two primary observations support a role for constitutive p38 MAP kinase activity in the regulation of cell volume. First, under isotonic conditions, inhibition of p38 with SB203580 increased membrane $\mathrm{Na}^{+}$permeability. Currents activated by SB203580 demonstrated biophysical properties that were identical to those of currents activated by hypertonic exposure, including a linear I-V relationship, equal permeability to $\mathrm{Na}^{+}$and $\mathrm{K}^{+}, \mathrm{Ca}^{2+}$-dependent regulation, and amiloride sensitivity. Second, exposure to SB203580 was followed by an increase in cell volume $(\sim 6 \%)$, consistent with an important role for p38 MAP kinase in the maintenance of resting cell volume under isotonic conditions.

While the inhibitory effects of SB203580 are detectable at low micromolar concentrations and appear to be specific for p38 $(50,51)$, it is acknowledged that SB203580 could have unanticipated effects on other signaling pathways. Consequently, an alternative strategy was used to evaluate the roles of recom- binant p38 $\alpha$ and the upstream MAP kinase kinase MEK- 6 on channel regulation. Intracellular delivery of these kinases inhibited volume-sensitive current activation. Indeed, intracellular delivery of active $p 38 \alpha$ resulted in a large shift in the activation curve, so that much higher degrees of hypertonicity were required before channel opening was observed. Dialysis with either p38 $\alpha$ or MEK- 6 alone resulted in only partial inhibition of currents, and dialysis with heat-inactivated $\mathrm{p} 38 \alpha$ had no effect. Thus, $\mathrm{p} 38 \alpha$, when present with its specific activator, is capable of channel inhibition. The partial effect observed with either p $38 \alpha$ or MEK- 6 alone may be related to activation of these proteins by endogenous cellular kinases. It is important to note that at higher degrees of hypertonicity $(50 \mathrm{mM}$ sucrose), NSC conductance could be activated even in the presence of $\mathrm{p} 38 \alpha$ and MEK- 6 . Thus, the inhibitory effect of P38 MAP kinase can be overcome by positive regulatory signals. In fact, there was no observable decrease in p38 activity with hypertonic exposure. Consequently, it will be important to define the additional regulatory pathways (regulatory proteins, cytoskeletal elements, insertion of new channels into the membrane, etc.) that are able to overcome the inhibitory effects of p38 and stimulate channel opening during hypertonic conditions.

The effects of p38 MAP kinase on membrane $\mathrm{Na}^{+}$permeability have several implications. First, while p38 has previously been shown to be an important regulator of transcription, these effects on $\mathrm{Na}^{+}$permeability imply that p38 MAP kinase has plasma membrane targets as well. Indeed, recent evidence suggests that p38 may modulate the $\mathrm{Na}^{+} / \mathrm{H}^{+}$exchanger (NHE-1) in vascular smooth muscle cells (15), $\mathrm{Ca}^{2+}$-activated, voltage-gated channels in neuronal cells (14), and acid secretion from gastric parietal cells (52). In all cases, p38 appears to have an inhibitory role, as observed here. However, whether p38 regulates channel function through a direct phosphorylation event or through downstream kinase pathways is yet to be determined. Second, while MAP kinase pathways were thought to mediate the effects of growth factors and hormones on sustained cellular events such as proliferation and differentiation, recent evidence has now emerged that MAP kinase pathways can also be activated by heterotrimeric $G$ proteins $(53,54)$ for rapid regulation of effector pathways $(55$, 56). For example, p38 3 appears to be involved in the regulation of $\mathrm{N}$-type calcium currents by bradykinin in a neuronal cell line, a response that occurs within seconds (14). Additionally, in neutrophils, p38 is activated within 2 minutes of exposure to formyl-methionyl-leucylphenylalanine (fMLP), an inflammatory stimulus, and modulates the response to hypertonic exposure (57). These studies support roles for p38 MAP kinase in rapid regulation of cellular events that are not necessarily related to gene transcription.

Assuming that $\mathrm{p} 38$ functions as a primary signal governing $\mathrm{Na}^{+}$influx and resting cell volume, several additional points merit further investigation. First, because 
the molecular identity of the NSC channel has not been established, the cellular site(s) of action of p38 is not clear. p38 may modulate channel activity by direct phosphorylation, or conversely, through effects on downstream kinases or phosphatases. Second, functional interactions between $\mathrm{p} 38$ and other kinases are likely to be operative. For example, preliminary evidence suggests that tyrosine kinase activity is also important in the response to cell volume changes $(58,59)$, and Src tyrosine kinase has been shown to be a direct regulator of ion channel function in different cell types (60). The sequence of action and relative importance of $\mathrm{p} 38$ versus other kinases has not been established, and is likely to be cell-type specific. For example, it should be noted that while PD98059 did not inhibit the response to hypertonic exposure, a role of ERK in channel regulation through MEK-1-independent pathways cannot be excluded. Lastly, a broad range of physiologic and pathologic stimuli modulate NSC channel activity, though the role of p38 in the mediation of these responses is largely unknown. However, p38 has been shown to play an important role in the insulin signaling pathway (61) as well as in responses to oxidative stress (38) and the initiation of apoptosis $(62,63)$, processes that are associated with alterations in cell volume $(20,64)$.

Taken together, these findings indicate that in HTC cells, p38 MAP kinase plays a key role in tonic inhibition of $\mathrm{Na}^{+}$permeability and maintenance of cell volume. It is clear, however, that the inhibitory effects of p38 MAP kinase are opposed by intracellular $\left[\mathrm{Ca}^{2+}\right]$ and presumably other stimulatory signals that work in concert to modulate $\mathrm{Na}^{+}$permeability in response to changing physiologic demands. Definition of the complex signaling pathways involved may provide new strategies for modulating liver cell function through effects on cell volume, and for minimizing cell injury caused by sustained $\mathrm{Na}^{+}$influx.

\section{Acknowledgments}

This study was supported by the Children's Hospital Research Institute Professional Development Award, the American Gastroenterological Association, the American Digestive Health Foundation, the Children's Digestive Health and Nutrition Foundation (A.P. Feranchak), and National Institute of Diabetes, Digestive and Kidney Diseases grants DK-43278 and DK-46082 (J.G. Fitz).

1. Paul, A., et al. 1997. Stress-activated protein kinases: activation, regulation and function. Cell Signal. 9:403-410.

2. Bode, J.G., et al. 1999. The mitogen-activated protein (MAP) kinase p38 and its upstream activator MAP kinase kinase 6 are involved in the activation of signal transducer and activator of transcription by hyperosmolarity. J. Biol. Chem. 274:30222-30227.

3. Han, J., Richter, B., Li, Z., Kravchenko, V., and Ulevitch, R.J. 1995. Molecular cloning of human p38 MAP kinase. Biochim. Biophys. Acta. 1265:224-227.

4. Han, J., Lee, J.D., Bibbs, L., and Ulevitch, R.J. 1994. A MAP kinase targeted by endotoxin and hyperosmolarity in mammalian cells. Science. 265:808-811.

5. Derijard, B., et al. 1995. Independent human MAP-kinase signal transduction pathways defined by MEK and MKK isoforms [erratum 1995, 269(5220):17]. Science. 267:682-685.

6. Raingeaud, J., Whitmarsh, A.J., Barrett, T., Derijard, B., and Davis, R.J. 1996. MKK3- and MKK6-regulated gene expression is mediated by the p38 mitogen-activated protein kinase signal transduction pathway. Mol. Cell. Biol. 16:1247-1255.

7. Raingeaud, J., et al. 1995. Pro-inflammatory cytokines and environmental stress cause p38 mitogen-activated protein kinase activation by dual phosphorylation on tyrosine and threonine. J. Biol. Chem. 270:7420-7426.

8. Kyriakis, J.M., et al. 1994. The stress-activated protein kinase subfamily of c-Jun kinases. Nature. 369:156-160.

9. Teague, T.K., et al. 1999. Activation changes the spectrum but not the diversity of genes expressed by $\mathrm{T}$ cells. Proc. Natl. Acad. Sci. USA. 96:12691-12696.

10. Nadkarni, V., Gabbay, K.H., Bohren, K.M., and Sheikh-Hamad, D. 1999. Osmotic response element enhancer activity. Regulation through p38 kinase and mitogen-activated extracellular signal-regulated kinase kinase. J. Biol. Chem. 274:20185-20190.

11. Wondergem, R., and Davis, J. 1994. Ethanol increases hepatocyte water volume. Alcohol. Clin. Exp. Res. 18:1230-1236.

12. Serrar, H., and Haddad, P. 1997. Effects of cold preservation and rewarming on rat liver cell volume regulation and concentrative amino acid uptake. Gastroenterology. 112:1344-1353.

13. Wettstein, M., and Haussinger, D. 1997. Cytoprotection by the osmolytes betaine and taurine in ischemia-reoxygenation injury in the perfused rat liver. Hepatology. 26:1560-1566.

14. Wilk-Blaszczak, M.A., et al. 1998. The mitogen-activated protein kinase p38-2 is necessary for the inhibition of N-type calcium current by bradykinin. J. Neurosci. 18:112-118.

15. Kusuhara, M., et al. 1998. p38 Kinase is a negative regulator of angiotensin II signal transduction in vascular smooth muscle cells: effects on $\mathrm{Na}^{+} / \mathrm{H}+$ exchange and ERK1/2. Circ. Res. 83:824-831.

16. Wehner, F., Sauer, H., and Kinne, R.K.H. 1995. Hypertonic stress increases the $\mathrm{Na}+$ conductance of rat hepatocytes in primary culture. J. Gen. Physiol. 105:507-535.

17. Wehner, F., and Tinel, H. 1998. Role of $\mathrm{Na}^{+}$conductance, $\mathrm{Na}+-\mathrm{H}+$ exchange and $\mathrm{Na}+-\mathrm{K}+-2 \mathrm{Cl}-$ symport in the regulatory volume increase of rat hepatocytes. J. Physiol. 506:127-142.

18. Lidofsky, S.D., Sostman, A., and Fitz, J.G. 1997. Regulation of cationselective channels in liver cells. J. Membr. Biol. 157:231-236.

19. Fitz, J.G., Sostman, A., and Middleton, J.P. 1994. Regulation of cation channels in liver cells by intracellular calcium and protein kinase C. Am. J. Physiol. 266:G677-G684.

20. Schlenker, T., Feranchak, A.P., Schwake, L., Stremmel, W., and Fitz, J.G. 2000. Functional interactions between oxidative stress, membrane $\mathrm{Na}+$ permeability, and cell volume in hepatoma cells. Gastroenterology. 118:395-403

21. Bodily, K., Wang, Y., Roman, R.M., Sostman, A., and Fitz, J.G. 1997. Characterization of a swelling-activated anion conductance in HTC hepatoma cells. Hepatology. 25:403-410.

22. Chang, D., Hsieh, P.S., and Dawson, D.C. 1988. Calcium: a program in BASIC for calculating the composition of solutions with specified free concentrations of calcium, magnesium and other divalent cations. Comput. Biol. Med. 18:351-366.

23. Lidofsky, S.D., Xie, M.H., Sostman, A., Scharschmidt, B.F., and Fitz, J.G. 1993. Vasopressin increases cytosolic sodium concentration in hepatocytes and activates calcium influx through cation-selective channels. $J$. Biol. Chem. 268:14632-14636.

24. Fitz, J.G., and Sostman, A. 1994. Nucleotide receptors activate cation, potassium, and chloride currents in a liver cell line. Am. J. Physiol. 266:G544-G553.

25. Roman, R.M., et al. 1997. Hepatocellular ATP-binding cassette protein expression enhances ATP release and autocrine regulation of cell volume. J. Biol. Chem. 272:21970-21976.

26. Berl, T., Siriwardana, G., Ao, L., Butterfield, L.M., and Heasley, L.E. 1997. Multiple mitogen-activated protein kinases are regulated by hyperosmolality in mouse IMCD cells. Am. J. Physiol. 272:F305-F311.

27. Wojtaszek, P.A., Heasley, L.E., Siriwardana, G., and Berl, T. 1998. Dominant-negative c-Jun NH2-terminal kinase 2 sensitizes renal inner medullary collecting duct cells to hypertonicity-induced lethality independent of organic osmolyte transport. J. Biol. Chem. 273:800-804.

28. Sluss, H.K., Barrett, T., Derijard, B., and Davis, R.J. 1994. Signal transduction by tumor necrosis factor mediated by JNK protein kinases. Mol. Cell. Biol. 14:8376-8384.

29. Dudley, D.T., Pang, L., Decker, S.J., Bridges, A.J., and Saltiel, A.R. 1995. A synthetic inhibitor of the mitogen-activated protein kinase cascade. Proc. Natl. Acad. Sci. USA. 92:7686-7689.

30. Young, P.R., et al. 1997. Pyridinyl imidazole inhibitors of p38 mitogenactivated protein kinase bind in the ATP site. J. Biol. Chem. 272:12116-12121.

31. Lee, J.C., Kassis, S., Kumar, S., Badger, A., and Adams, J.L. 1999. p38 mitogen-activated protein kinase inhibitors-mechanisms and therapeutic potentials. Pharmacol. Ther. 82:389-397.

32. New, L., et al. 1998. PRAK, a novel protein kinase regulated by the p38 MAP kinase. EMBO J. 17:3372-3384. 
33. Bohmer, C., and Wehner, F. 2001. The epithelial $\mathrm{Na}(+)$ channel (ENaC) is related to the hypertonicity-induced $\mathrm{Na}(+)$ conductance in rat hepatocytes. FEBS Lett. 494:125-128.

34. Feranchak, A.P., Roman, R.M., Schwiebert, E.M., and Fitz, J.G. 1998. Phosphatidylinositol 3-kinase represents a novel signal regulating cell volume through effects on ATP release. J. Biol. Chem. 273:14906-14911.

35. Han, J., et al. 1996. Characterization of the structure and function of a novel MAP kinase kinase (MKK6). J. Biol. Chem. 271:2886-2891.

36. Enslen, H., Raingeaud, J., and Davis, R.J. 1998. Selective activation of p38 mitogen-activated protein (MAP) kinase isoforms by the MAP kinase kinases MKK3 and MKK6. J. Biol. Chem. 273:1741-1748.

37. Stein, B., Brady, H., Yang, M.X., Young, D.B., and Barbosa, M.S. 1996. Cloning and characterization of MEK6, a novel member of the mitogenactivated protein kinase kinase cascade. J. Biol. Chem. 271:11427-11433.

38. Mendelson, K.G., Contois, L.-R., Tevosian, S.G., Davis, R.J., and Paulson, K.E. 1996. Independent regulation of JNK/p38 mitogen-activated protein kinases by metabolic oxidative stress in the liver. Proc. Natl. Acad. Sci. USA. 93:12908-12913.

39. Tohda, H., Foskett, J.K., O’Brodovich, H., and Marunaka, Y. 1994. Cl- regulation of a calcium-activated nonselective cation channel in beta-agonist-treated fetal distal lung epithelium. Am. J. Physiol. 266:C104-C109.

40. Koch, J.P., and Korbmacher, C. 2000. Mechanism of shrinkage activation of nonselective cation channels in M-1 mouse cortical collecting duct cells. J. Membr. Biol. 177:231-242.

41. Marunaka, Y., and Niisato, N. 2001. The essential role of cytosolic Cl- in $\mathrm{Ca} 2+$ regulation of an amiloride-sensitive channel in fetal rat pneumocyte. J. Membr. Biol. 180:91-99.

42. Chiba, T., and Marcus, D.C. 2000. Nonselective cation and BK channels in apical membrane of outer sulcus epithelial cells. J. Membr. Biol. 174:167-179.

43. Broillet, M.C., and Firestein, S. 1999. Cyclic nucleotide-gated channels. Molecular mechanisms of activation. Ann. NY Acad. Sci. 868:730-740.

44. Finn, J.T., Grunwald, M.E., and Yau, K.W. 1996. Cyclic nucleotide-gated ion channels: an extended family with diverse functions. Annu. Rev. Physiol. 58:395-426.

45. Frings, S., Lynch, J.W., and Lindemann, B. 1992. Properties of cyclic nucleotide-gated channels mediating olfactory transduction. Activation, selectivity, and blockage. J. Gen. Physiol. 100:45-67.

46. Vandorpe, D.H., Ciampolillo, F., Green, R.B., and Stanton, B.A. 1997. Cyclic nucleotide-gated cation channels mediate sodium absorption by IMCD (mIMCD-K2) cells. Am. J. Physiol. 272:C901-C910.

47. Kleene, S.J. 2000. Spontaneous gating of olfactory cyclic-nucleotidegated channels. J. Membr. Biol. 178:49-54.

48. Marunaka, Y., Tohda, H., Hagiwara, N., and O’Brodovich, H. 1992. Cytosolic $\mathrm{Ca}(2+)$-induced modulation of ion selectivity and amiloride sensitivity of a cation channel and beta agonist action in fetal lung epithelium. Biochem. Biophys. Res. Commun. 187:648-656.

49. Marunaka, Y., Tohda, H., Hagiwara, N., and Nakahari, T. 1994. Antidi- uretic hormone-responding nonselective cation channel in distal nephron epithelium (A6). Am. J. Physiol. 266:C1513-C1522.

50. Whitmarsh, A.J., Yang, S.H., Su, M.S., Sharrocks, A.D., and Davis, R.J. 1997. Role of p38 and JNK mitogen-activated protein kinases in the activation of ternary complex factors. Mol. Cell. Biol. 17:2360-2371.

51. Wang, Z., et al. 1998. Structural basis of inhibitor selectivity in MAP kinases. Structure. 6:1117-1128.

52. Pausawasdi, N., Ramamoorthy, S., Stepan, V., del Valle, J., and Todisco, A. 2000. Regulation and function of p38 protein kinase in isolated canine gastric parietal cells. Am. J. Physiol. Gastrointest. Liver Physiol. 278:G24-G31.

53. Crespo, P., Xu, N., Simonds, W.F., and Gutkind, J.S. 1994. Ras-dependent activation of MAP kinase pathway mediated by G-protein beta gamma subunits. Nature. 369:418-420.

54. Yamauchi, J., Nagao, M., Kaziro, Y., and Itoh, H. 1997. Activation of p38 mitogen-activated protein kinase by signaling through $\mathrm{G}$ protein-coupled receptors. Involvement of Gbetagamma and Galphaq/11 subunits. J. Biol. Chem. 272:27771-27777.

55. Ruis, H., and Schuller, C. 1995. Stress signaling in yeast. Bioessays. 17:959-965.

56. Waskiewicz, A.J., and Cooper, J.A. 1995. Mitogen and stress response pathways: MAP kinase cascades and phosphatase regulation in mammals and yeast. Curr. Opin. Cell Biol. 7:798-805.

57. Junger, W.G., et al. 1998. Hypertonicity regulates the function of human neutrophils by modulating chemoattractant receptor signaling and activating mitogen-activated protein kinase p38. J. Clin. Invest 101:2768-2779

58. Krump, E., Nikitas, K., and Grinstein, S. 1997. Induction of tyrosine phosphorylation and $\mathrm{Na}+\mathrm{H}+$ exchanger activation during shrinkage of human neutrophils. J. Biol. Chem. 272:17303-17311.

59. Szaszi, K., Buday, L., and Kapus, A. 1997. Shrinkage-induced protein tyrosine phosphorylation in Chinese hamster ovary cells. J. Biol. Chem. 272:16670-16678.

60. Hilborn, M.D., Vaillancourt, R.R., and Rane, S.G. 1998. Growth factor receptor tyrosine kinases acutely regulate neuronal sodium channels through the src signaling pathway. J. Neurosci. 18:590-600.

61. Heidenreich, K.A., and Kummer, J.L. 1996. Inhibition of p38 mitogenactivated protein kinase by insulin in cultured fetal neurons. J. Biol. Chem. 271:9891-9894

62. Kummer, J.L., Rao, P.K., and Heidenreich, K.A. 1997. Apoptosis induced by withdrawal of trophic factors is mediated by p38 mitogen-activated protein kinase. J. Biol. Chem. 272:20490-20494.

63. Nemoto, S., Xiang, J., Huang, S., and Lin, A. 1998. Induction of apoptosis by SB202190 through inhibition of p38beta mitogen-activated protein kinase. J. Biol. Chem. 273:16415-16420.

64. Maeno, E., Ishizaki, Y., Kanaseki, T., Hazama, A., and Okada, Y. 2000. Normotonic cell shrinkage because of disordered volume regulation is an early prerequisite to apoptosis Proc. Natl. Acad. Sci. USA. 97:9487-9492. 